\title{
The Trade Specialization Index (TSI) of Indonesian Seaweeds
}

\author{
Harsuko Riniwati ${ }^{1}$, Sutinah Made $^{2}$, Adriana Monica Sahidu ${ }^{3}$ \\ \{riniwatisepk@ub.ac.id ${ }^{1}$ \} \\ Universitas Brawijaya, Indonesia ${ }^{1}$ \\ Universitas Hasanudin, Indonesia ${ }^{2}$ \\ Universitas Airlangga, Indonesia ${ }^{3}$
}

\begin{abstract}
Trade Specialization Index (TSI) is employed to analyze the position or stage of product development. TSI index can describe certain types of products, whether Indonesia has a tendency to be the exporting or importing country. The purpose of this study was to analyze the Indonesian Seaweed Trade Specialization Index. The data were obtained from the secondary data, namely the UN Comtrade in 2017 and 2018. The data presented the value of seaweed commodity exports to all countries in the world and the value of seaweed imports during 2017 and 2018. The formula used in analyzing this Trade Specialization Index was the Indonesian export value minus the import of seaweed then the result was compared to the total value of exports and imports of Indonesian seaweed. The calculation results indicated that the Indonesian Seaweed Trade Specialization Index was 0.93 . This suggests that Indonesia has strong competitiveness or Indonesia has a tendency to be an exporter of seaweed commodities. Therefore, it can be concluded that Indonesian seaweed supply is greater than domestic demand.
\end{abstract}

Keywords: Exporting Country, Importing Country, Seaweed, Trade Specialization Index.

\section{Introduction}

President Joko Widodo's speech [1] at the presidential inauguration on October 20, 2019 states that in the next 5 years, President and his ministers will carry out several programs: First, human resources development will be Indonesia's top priority. It can be achieved by developing hard working and dynamic human resources; skilled human resources that master science and technology; and inviting global talents to work with the government. If it cannot be accomplished by using old method, then new method will be developed. The government needs 7 large endowment funds for Indonesian human resources management. Next, the optimization of industry collaboration can be done by utilizing technology that could reach all corners of the country. Second, the government will be developing infrastructure since it can connect production area with distribution area, facilitatting access to tourist areas, boosting new jobs, and accelerating people's economy added value.

Third, all forms of regulatory constraints should be simplified and cut by the government. The government will invite the House of Representatives to issue 2 major laws: 1) Employment Copyright Law, 2) Law on SMEs (UMKM) Empowerment. Each of these laws will become an Omnibus that revises several laws especially laws that hamper job creation 
and SMEs development. Fourth, bureaucracy simplification should be continuously carried out on a large scale by prioritizing job creation investment. Long procedures, bureaucracy, and echelon system should be simplified since there are too many echelons. The system should be arranged into two levels only by replacing functional positions valuing expertise with functional positions valuing competence. Next, the President also requires ministers, officials and bureaucrats to seriously ensure the development program objectives' achievements. Dealing with those who fail to carry out their job, the president will act decesively by suspending them from their current positions. Next, the fifth is about economic transformation. Government should transform itself from natural resources dependency into being a competitive country on modern manufacturing and services that have high added value aiming at Indonesians prosperity and social justice.

How does seaweed commodity contribution support Indonesia's objectives? Hence, the trade specialization index will be utilized since Indonesia is the largest seaweed exporter in the world. Two major seaweed exporter countries are: Indonesia (US \$ 209,142,410), and Chile (US \$ 101,631,264). Indonesia seaweed export volume is at $201,161,747 \mathrm{~kg}$. This volume shows the largest market share of Indonesia's seaweed by 44.282 percent and the second place comes from Ireland at 76,831,476 kg (UN Comtrade. 2018). Although Chile has low seaweed export volume, it has high seaweed export value. It means that Chilean seaweed exports value is classified as high rate. The higher seaweed export prices mean the higher seaweed added value (in the processed form).

However, the stated data will be meaningless if there is no index analysis reflecting substantial information for developing policy. One of the indexes that can be used to determine the competitiveness position and seaweed commodity growth level is the Trade Specialization Index. Hence, it is used to analyze the position or product development stage. It can describe whether Indonesia tends to be an exporting or importing country (https://www.kemendag.go.id/addon/isp/). Moreover, it can also be used to identify the growth rate of a commodity in trade which is divided into 5 stages as follows:

a) The Introduction Stage is when an industry (forerunner) in a country (call A) exports new products and a later comer industry in country B imports those products. In this stage, the ISP index value of the later comer industry is -1.00 to -0.50 .

b) The Import Substitution Stage is when ISP index value rises between -0.51 to 0.00 . At this stage, industry in country B shows very low competitiveness attitude, because the level of production is not high enough to reach its economics scale. The industry exports poor quality products and domestic production is limited than domestic demand. In short, at this stage country B imports more than exports.

c) The Growth Stage takes place when ISP index value rises between 0.01 to 0.80 , and industries in country B produce large-scale production and begin to increase exports. In the domestic market, supply for these commodities is greater than demand.

d) The Maturity Stage, namely the index value is in the range of 0.81 to 1.00 . At this stage, the product concerned is already at standardization stage concerning the technology it contains. Country B is considered as a net exporter country.

e) The stage of re-importing is when ISP index value decreases between 1.00 to 0.00 . At this stage, industries in country B are unable to compete within their domestic markets with industries from country A, and domestic production is less than domestic demand.

The purpose of this study was to analyze 1) seaweed trade specialization index and 2) seaweed commodity growth level. 


\section{Research Method}

Indonesian seaweed market specialization index was analyzed by using the following formula:

$$
\begin{aligned}
\text { Trade Specialization Index }(\mathrm{ISP})= & \left(\underline{\mathrm{X}_{\underline{\mathrm{i}}}-}-\mathrm{M}_{\underline{\mathrm{ia}}}\right) \\
& \left(\mathrm{X}_{\mathrm{ia}}+\mathrm{M}_{\mathrm{ia}}\right)
\end{aligned}
$$

Notes:

$\mathrm{Xia}=$ Indonesian seaweed export value

Mia $=$ Indonesian seaweed import value

The data of Indonesian seaweed values were obtained from UN Comtrade https://comtrade.un.org/data. This Trade Specialization Index considered both demand and supply. It was based on surplus net theory; where exports of goods occur when there is an excess of these goods on the domestic market. This index value ranged between -1 to +1 . If the value was positive above 0 to 1 , the commodity was assumed to have strong competitiveness attitude or the country concerned tended to be an exporter of the commodity (domestic supply was greater than domestic demand). However, if the competitiveness was low or the country tended to be an importer (domestic supply was smaller than domestic demand), when the value was negative or it was below 0 to -1 . If the index rose, it meant that competitiveness increased, and vice versa.

\subsection{Indonesian Seaweed Market Specialization Index}

Researchers use the Trade Specialization Index to analyze product development stage. It could describe whether Indonesia tended to be an exporter or importer country. The second objective of this research was to analyze Indonesian's seaweed Trade Specialization Index. The data was obtained from secondary data (UN Comtrade in 2017 and 2018) presenting seaweed commodity export value and seaweed import value since 2017 - 2018.

The formula used was as follows: the export value minus the import value of Indonesian seaweed was divided by the total value of export and import of Indonesian seaweed.

Note:

$$
\text { Trade Specialization Index (ISP) }=\frac{\left(\mathrm{X}_{\mathrm{ia}}-\mathrm{M}_{\mathrm{ia}}\right)}{\left(\mathrm{X}_{\mathrm{ia}}+\mathrm{M}_{\mathrm{ia}}\right)}
$$

$\mathrm{Xia}=$ Indonesian seaweed export value

Mia $=$ Indonesian seaweed import value

Based on UN Comtrade data of 2017-2018, Indonesian seaweed export value was US \$ $135,283,128$ and the import value was US $\$ 4,887,538$. Hence, Indonesian seaweed trade specialization index was (US \$ 135,283,128 - US \$ 4,887,538): (US \$ 135,283,128+ US \$ $4,887,538)=0.93$. This showed that Indonesia has strong competitiveness or Indonesia tends to be seaweed exporter. It can be concluded that Indonesian seaweed domestic supply is greater than the domestic demand.

When index value ranged within 0.81 to 1.00 , it meant the product concerned was already at the standardization stage. Furthermore, it also meant that country B was a net exporter country. By referring to ISP curve, Indonesian seaweed products was at stage 4 or maturity. 


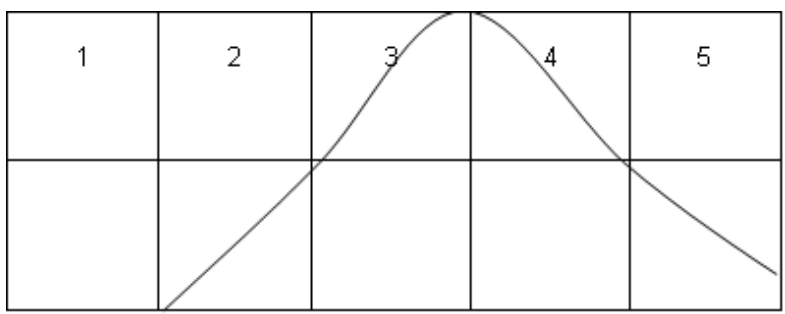

1. Introduction Stage

2. Import Substitution Stage

3. Growth Stage

4. Maturity Stage

5. Re-import Stage

Fig.1. ISP curve from Product Cycle Theory.

The seaweed commodity's Trade Specialization Index is closely related to excess demand and supply. It is also related to commodity competitiveness either as exporter or importer. If a country wanted to be an exporting country, that country could create excess supply to be exported to countries which had excess demand. The detail illustrations of excess supply and demand can be seen in Figure 2.

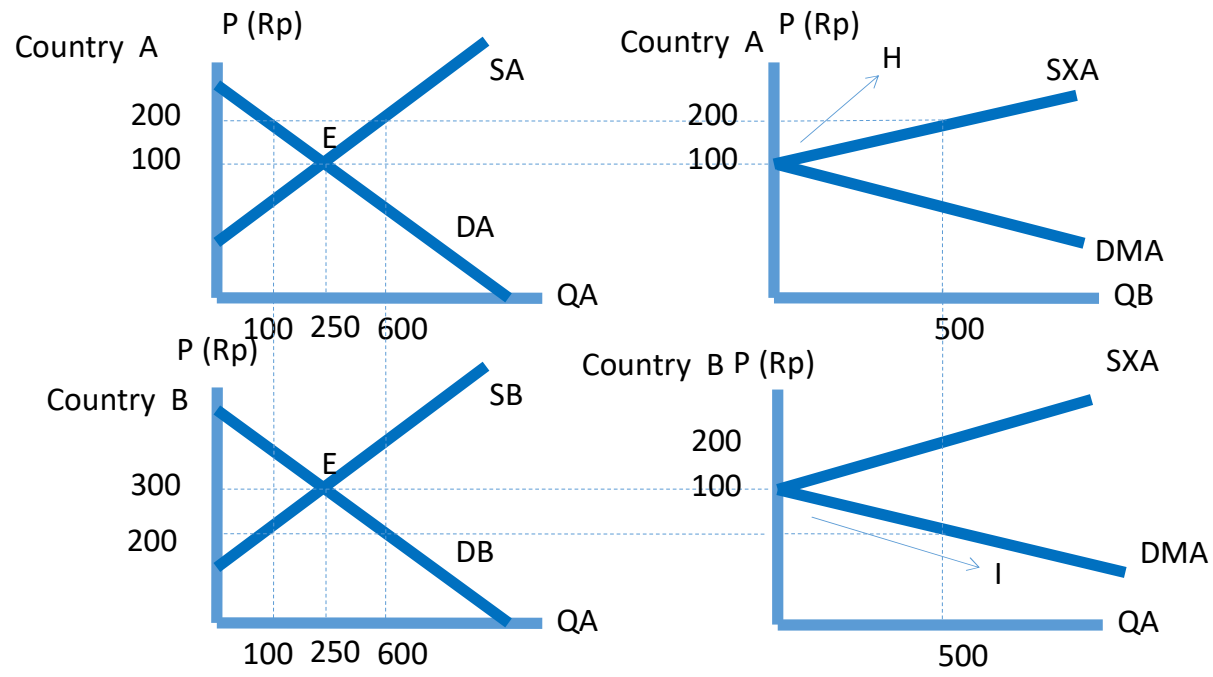

Fig. 2. Excess supply and demand.

For example, there were 2 countries; $\mathrm{A}$ and $\mathrm{B}$.

a) When the price of goods is Rp. 100 per unit in country A, and there are 250 units, the country reaches equilibrium point. However, when the price rises to Rp. 200 per unit, country A experiences excess offered goods (excess supply) domestically at 600 $100=500$. The excess quantities of offered goods are exported (SXA) to country B.

b) In country B, when the price of goods is Rp. 300 per unit and there are 250 units, the country reaches equilibrium (E) point. However, when the price drops to Rp. 200 per unit, the country experiences an excess amount of demanded goods domestically. Then country B will import to meet that demands. 
Theoretically, an increase in competitiveness could be made by creating excess supply which would be exported to countries that had excess demand for the same commodity. Creating competitiveness means creating opportunities. According to Riniwati [2], opportunities were formed from 3 indicators namely natural resources, human resources and artificial resources (technology, markets, capital and training). Opportunity had a significant positive effect on motivation and performance. Therefore, to improve competitiveness, support from various parties were needed, for example, motivation through the processing of natural resources by developing human resources and artificial resources; technology; markets; capital; and training.

It is the time for international seaweed trade to improve its competitiveness in developing processed products that have high added value, and increase the international trade balance surplus. According to Budiono [3], the economic balance of 4 sectors are:

$$
\mathrm{Y}=\mathrm{C}+\mathrm{I}+\mathrm{G}+(\mathrm{X}-\mathrm{M})
$$

In which,

$\mathrm{Y}=$ income, $\mathrm{C}=$ consumption, $\mathrm{I}=$ investment, $\mathrm{G}=$ government expenditure, $\mathrm{X}=$ export value, $\mathrm{M}=$ import value

From this formula, if export value was higher than import value, then a country's international trade balance would be surplus. However, if import value was higher than export value, an international trade balance deficit would be occurred. If the export value was from low-priced raw materials and the import value was from processed products having high added value and price, there was a concern that Indonesian seaweed international trade balance would experience deficit.

Moreover, Indonesia is still dominant in exporting raw seaweed compared to processed products. If Indonesia could increase seaweed exports from raw to processed seaweed, the added value and export value would be higher. For example, the price of raw exported seaweed material is US \$ 0.3 per kilogram. However, if Indonesia imports it in the form of SRC (semi reined Carrageenan) the price would be 6 US dollars/Kg and if it is in finished form as Carrageenan powder the price would be 10 US dollars/Kg [4].

Seaweed cultivation in developing countries improves community's economic and social status. In addition, government's empowerment on fishing communities also aims to reduce ecological pressure on marine resources. Seaweed farming development in Indonesia transforms the socio-economic structure. Changes in the main livelihood activities from capture fisheries to seaweed cultivation prove that seaweed cultivation leverages household economic condition of coastal community. This transition is expected having long-term ecological implications for coastal environments sustainability and for behavioral change among coastal populations especially for those who are dependent on fisheries. Seaweed cultivation could be used as a complement or a support for fishermen's income at low catch fish times [5].

Then, how to increase the added value of processed seaweed to leverage seaweed price and seaweed farmers' income? What is the problem in seaweed processing industry? Based on in depth interview with seaweed farmers and processors in Sumenep Madura, it deals with technology use. It still utilizes manual technology. This condition leads into a very low processing rate while the production rate of seaweed cultivation is very high. Hence, the processing industry can not fully absorb raw seaweed produced from sea aquaculture. Similar 
thing also happens to the domestic market; therefore, seaweed exports are in form of raw seaweed.

Hence, seaweed industry development is susceptible to seaweed-based products processing and export marketing based. There is an inverse relationship between vulnerability and capacity Riniwati, et al [6]. The higher the vulnerability, the lower the capacity would be. Therefore, to eliminate vulnerability, capacity should be increased. The slack of seaweed processing industry development in Indonesia could be eliminating by increasing seaweed processing capacity.

Result taken form another competitiveness index, namely the Herfindahl-Hirschman index (IHH) also showed the same thing Riniwati [7]. It depicted the position of high concentration seaweed in market structure, namely, the monopsony competition market with big players. It consisted only two countries, Indonesia and Chile.

If it was related to competitiveness, then it was very closely related to market dominance or market share, market concentration, and market structure. Based on the data from UN Comtrade [7], Indonesia's seaweed export value ranked as one in the world. Indonesia's seaweed market coverage in international trade was also at the highest rank $(44.282 \%)$. The market share of a particular commodity was related to market concentration or market structure that occurred. To understand worldwide seaweed trade' market share was by comparing the proportion of country's total seaweed exports to the total seaweed exports in certain industries over certain period of time. Market share was usually expressed as a percentage since it depicted the market concentration of a commodity. It was divided into 3 categories namely high, medium and low concentration markets. Furthermore, market concentration showed the market structure which was divided into 4 categories, namely perfect competition, oligopoly, monopolistic competition, and monopoly.

Nur Hendra and Hartomo [8] explained that market structure was market organization characteristic that influenced the nature of market's competition and prices. The forms of market structure, included:

a) Perfect Competition Market is a form of interaction between demand and supply where the number of buyers and sellers is unlimited.

b) Imperfect Competition Market is a market which was not perfectly organized where one of the characteristics of a perfect competition market is not fulfilled. Imperfect competition consists of monopolistic, oligopoly, and monopolistic competition markets.

Lindung and Jamil's research [9], explained that a country's commodity market structure was described by how much market share owned by each exporting country. In other words, control showed the influence of a particular country's commodities on total world trade. In worldwide seaweed trade, the two countries that could control the trade share, were Indonesia and Chile. Both countries, in 2018, had market share of $44.282 \%$ (Indonesia) and 21.518\% (Chile), respectively.

In a perfect competition market, where products are indistinguishable, competition is fierce and no company has the power to change market prices. In such market, prices are determined at market level by the power of supply and demand. Thus, from company's point of view, the price of their product is given. The competition strength limits strategic wisdom and pushes profits to normal levels, which is not enough to attract new entrants to the market [10].

Commodity's market is seen competitive, because there is no single producer that could change market prices. Perfect markets are uncommon. Companies have big incentives to adopt strategies that avoid 'strategic engineering' of perfect competition. In other conditions, the market is a monopoly if only one company supplies the entire market. Companies could set 
prices, and therefore, enjoy controlling their market environment and significant market power. The high level of market power allows monopolistic companies to get higher profits than competitive companies.

Next, there is an oligopolistic market, where several companies compete with each other, and monopolistic competition. Most economists consider these intermediate cases as the norm. In monopolistic competition, there are many companies, where each small market share company is able to differentiate its products to a certain degree, and to gain simple control over prices. Furthermore, those companies also build competitive advantage over other players by maximizing different aspects of its strategy.

In the oligopolistic market, each player could gain a competitive advantage by exploiting economiecs scale; by creating product differentiation; and so on. At both cases, several companies compete with each other. This competition could be muted due to the occurrence of collusion between companies aiming at reducing competition. Although it is possible and could give market control to all connected producers, and would improve the financial performance of both individual companies and the sector as a whole, however, it is sometimes difficult to create and maintain, and illegal too. Intense competition could also happen in oligopolistic markets. Every company knows that in this case, effective strategic management can create competitive advantage, yet each requires also to realize that the competitors can imitate every strategic move.

It is important to observe the threat from new entrants which is technically known as a 'contested market'. Sometimes it is very low, due to large entry fee. This price comes from the large fixed costs for plant installations, as well as the costs for obtaining key competencies from the business. Based on UN Comtrade data [7], Indonesia was the largest seaweed exporting country in the world. Indonesia also has the largest market share in the world.

Next, it can be further analyzed whether the international seaweed trade in the world has a low, medium or high market concentration. The conditions of world seaweed market concentration can be observed by using the Herfindahl-Hirschman Index (IHH). Furthermore, the composition of seaweed export values from 32 countries can be seen in the figure 3 .

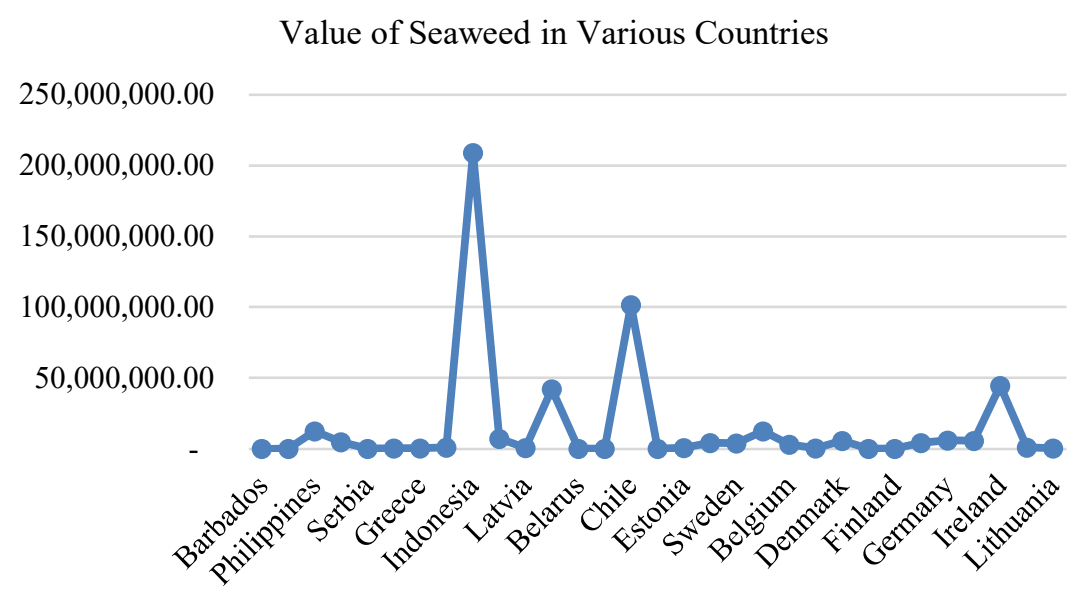

Fig. 3. Seaweed export values.

The calculation results by using the above table formula shows that worldwide seaweed concentration market is very high. This reflected that the market structure was highly 
concentrated in some of the biggest seaweed exporting countries. Among the top 5 of world seaweed exporters, from rank 1-5, they are as follows: 1) Indonesia, 2) Chile, 3) Ireland, 4) Portugal, 5) Philippines. The worldwide seaweed market concentration could be regarded as very concentrated due to the IHH of 2,616 (more than 2,500). The Herfindahl-Hirschman index $(\mathrm{IHH})$ explanation related to market concentration can be seen in Figure 4.

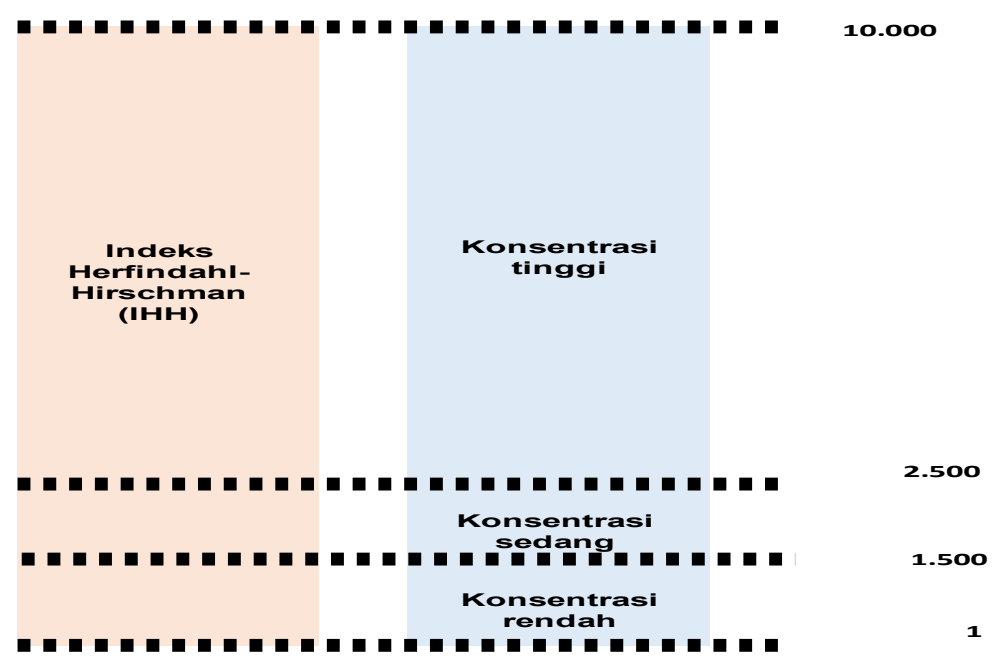

Fig. 4. Market concentration level on the Herfindahl-Hirschman index.

Next, sales volume affects the market shape, namely: perfect competition, monopolistic competition, oligopoly, or monopoly. This will affect the size of sales distribution which is reflected by sales number in the market. The number of sellers can influence market's behavior, because the number of sellers affects company's expectations of its competitors' behaviors. Furthermore, the number and size of sales distribution can also affect prices as it is measured by market forces. Market power is company's ability to influence market prices and/or to beat competitors which is further studied by industrial economics.

Based on seaweed export value data when it is divided by seaweed export volume, it will reflect seaweed export prices in international trade. How does the price of Indonesian seaweed in world trade? If the price of seaweed exported is high, it reflects that the product being exported has high added value. On the contrary, if the exported seaweed has a low price, it means that the seaweed is exported as raw seaweed. Indonesia's competitiveness in terms of seaweed exports is at a high level of concentration. It can be assumed as a player in the monopsony competition market structure where the dominating players were very few.

However, the price of exported Indonesian seaweed is low since it is exported in the form of raw seaweed. If Indonesia's import value of processed seaweed products is high, Indonesia will cause a large international trade balance deficit in seaweed commodities. Therefore, to get a bigger gap on the difference of seaweed export value and import value, Indonesia's competitiveness on seaweed exports is needed to be increased by producing more processed seaweed products that have added value and high prices.

The price factor is negatively related to shrimp export volume [11] and applies generally to all products including seaweed. Thus, if seaweed export prices are increased, it will reduce the volume of seaweed exports. If the situation starts with the increasing price, the export 
volume will decrease. However, if it begins with the decreasing volume, the price will rise. Thus, if we want to increase seaweed prices, the export volume should be lowered, especially for raw seaweed. Next, processed seaweed products exports can be increased by using seaweed export volume reduction since using modern processing technology. Indonesian seaweed export prices can be seen in Figure 5.

\section{Prices of Exported Seaweed from Various Countries in} 2018

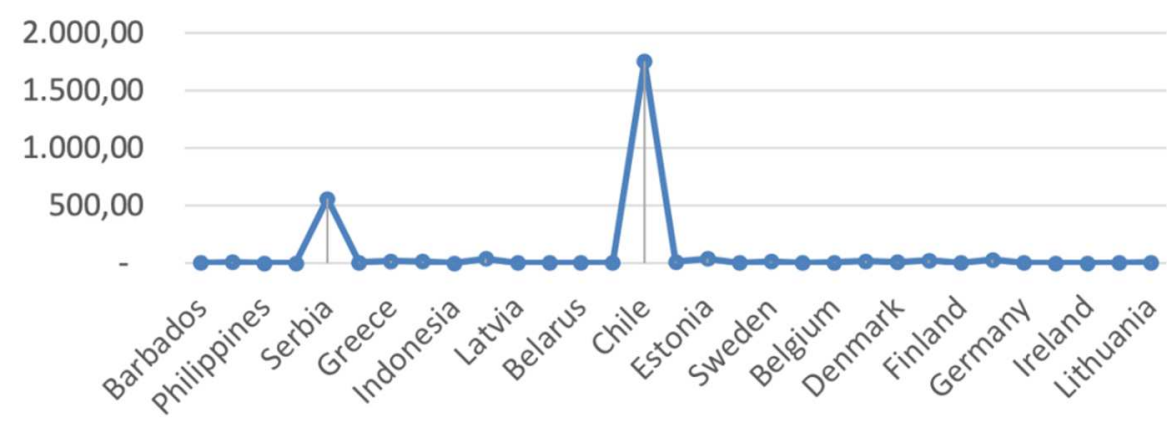

Fig. 5. The Export Price of Indonesian Seaweed in International Trade.

The above description shows that Indonesian raw seaweed competitiveness has a strong position, where Indonesia is categorized as seaweed exporting country. Based on market concentration analysis, Indonesia is included in high concentrations market, namely monopsony competition between Indonesia and Chilli. Here, the difference lies on the price. Indonesian's seaweed is cheaper than Chilean's seaweed. This shows the difference in competitiveness of value added (raw versus processed). The market specialization index also shows that product growth is at maturity level. This means that Indonesia shows remarkable achievements in raw seaweed. To increase the gap between export value and import value, Indonesia needs to create excess supply that meets export standard so that the international trade balance surplus of seaweed is very high. Next, to maintain Indonesia's achievements in international market, processed seaweed products can be employed so that the gap between export value and import value would go widens. Hence, it means that the trade balance surplus contribution from seaweed is increased too.

Wiwoho, et al [12] state that an aggressive strategy for mass tourism into ecotourism development with co-management pattern between local governments and the community should be done by increasing community ability to be more creatively and innovatively developed. It is important since it works to improve and to create the competitiveness of processed seaweed based. It can be administered by using co-management between local government, local community, and investors.

Previous studies showed that community empowerment variable had a very significant influence on the responsible behavior for conservation. Next, geographical and land variables had a very significant influence on conservation; and local institutional factors, facilities and infrastructure had a higher influence than other factors. The institutional factors, facilities, and infrastructure could be utilized as a model of community empowerment [13]. Nugroho, et.al research showed community empowerment lead into responsible behavior that could be also developed for SMEs seaweed empowerment by employing local institutions and 
infrastructure. Co-management between local government, local institutional, investors was related to empowerment and support of infrastructure.

Harahab et al [14] showed that the vulnerability in bringing high ecotourism was associated with socio-economic and demographic dimensions, and community participation. By combining Harahab, et al [14] and Nugroho, et al [13] findings, the best way to leverage community empowerment is by applying co-management that involves local government, community participation, local institutions, and investor.

\section{Conclusions}

The conclusions of this study are: a) Indonesia is a country that exports raw seaweed; b) Indonesia's product cycle is at the maturation stage.

\subsection{Suggestions}

a) Indonesia needs to improve and create its competitiveness by applying a co-management strategy between local government, local communities, local investor, and institutions.

b) Indonesia needs to maintain its product cycle to remain at the maturity stage by creating excess supply of processed seaweed and by identifying countries in the world that experience excess demand for processed seaweed products.

\section{References}

[1] Anonymous, "Naskah Lengkap Pidato Presigen Joko Widodo dalam Pelantikan Periode 20192024," 2019. .

[2] H. Riniwati, "Blue Economy in Motion: The Role of Ability, Opportunity, and Motivation of Human Resource to Performance of Organization," Ecol. Environ. Conserv. Pap, vol. 22, pp. 567-576, 2016.

[3] Budiono, Teori Ekonomi Makro. Yogyakarta: BPFE, 1998.

[4] T. K. Siang, D.R.; Isamu, "Analisis Ketidakseimbangan Penawaran dan Permintaan Eksport Rumput Laut (Eucheuma cottonii) di Sulawesi Selatan,” 2005. [Online]. Available: Roslindajs.blogspot.com/2011/03/analisis-ketidakseimbangan-penawaran.html. [Accessed: 31Jan-2019].

[5] A. Zamroni, K. Laoubi, and M. Yamao, "The development of seaweed farming as a sustainable coastal management method in Indonesia: an opportunities and constraints assessment," WIT Trans. Ecol. Environ., vol. 150, pp. 505-516, 2011.

[6] H. Riniwati, N. Harahab, and Z. Abidin, "A vulnerability analysis of coral reefs in coastal ecotourism areas for conservation management," Diversity, vol. 11, no. 7, p. 107, 2019.

[7] Un Comtrade, "Seaweeds and other algae. Of a kind use primary for human consumption. Fresh, chilled, frozen or dried whether or not ground," 2018. .

[8] S. T. N. Hendra and D. D. Hartomo, "Pengaruh Konsentrasi dan Pangsa Pasar terhadap Pengambilan Resiko Bank," J. Bisnis dan Manaj. (Journal Bus. Manag., vol. 17, no. 2, pp. 3550, 2017.

[9] L. Lindung and A. S. Jamil, "Posisi Daya Saing Dan Tingkat Konsentrasi Pasar Ekspor Karet Alam Indonesia Di Pasar Global," J. AGRISEP Kaji. Masal. Sos. Ekon. Pertan. dan Agribisnis, vol. 17, no. 2, pp. 119-128, 2018.

[10] J. Knight, B.; McGee, "Market Structure: The Analysis of Markets and Competition," Wiley Encycl. Manag., vol. 12, 2015. 
[11] H. Riniwati, N. Harahab, and T. Y. Carla, "Analysis of Indonesian Crab Export Competitiveness in International Market," Int. Rev. Manag. Mark., vol. 7, no. 5, pp. 23-27, 2017.

[12] S. P. H. Wiwoho, A. Hakim, H. Riniwati, and A. S. Leksono, "Analysis of Community-Based Educational Ecotourism Development Policy in Taman Beach Area, Pacitan Regency," in IOP Conference Series: Earth and Environmental Science, 2019, vol. 239, no. 1, p. 12047.

[13] M. Nugroho, H. Riniwati, and A. Afandhi, "Model of Community Empowerment of Springs Preservation in Arjuna Mountains," in IOP Conference Series: Earth and Environmental Science, 2019, vol. 239, no. 1, p. 12044.

[14] N. Harahab, H. Riniwati, and Z. Abidin, "The Vulnerability Analysis of Mangrove Forest Status as a Tourism Area," Ecol. Environ. Conserv. Pap, vol. 24, pp. 968-975, 2018. 